UNIWERSYTET

SZCZECIŃSKI

Zeszyty

Naukowe

n r 858
Wspótczesne

Problemy

Ekonomiczne

$n r 11(2015)$

DOI: $10.18276 /$ wpe.2015.11-02

\title{
Monika Kępa*
}

\section{Polityka makroostrożnościowa jako nowe wyzwanie banku centralnego}

Słowa kluczowe: kryzys finansowy, polityka makroostrożnościowa, bank centralny, nadzór makroostrożnościowy, stabilność sektora finansowego

Keywords: financial crisis, macro-prudential policy, central bank, macro-prudential supervision, stability of financial sector

\section{Wprowadzenie}

W dotychczasowej praktyce dominującym (ustawowym) celem banku centralnego była stabilność cen, co oznaczało dbałość o wartość pieniądza, o ustabilizowany niski poziom i dynamikę inflacji. Doświadczenia ostatniego kryzysu wykazują, iż nie jest to cel wystarczający. Wskazuje się, iż celem banku centralnego powinna być również stabilność systemu finansowego, co oznacza między innymi powierzenie bankowi centralnemu nadzoru makroostrożnościowego ${ }^{1}$.

Nadzór makroostrożnościowy (macroprutential) ${ }^{2}$ koncentruje się na zapewnieniu stabilności całego systemu finansowego lub jego istotnej części. W szczególności nadzór ten odpowiada za identyfikację i analizę ryzyka systemowego oraz powinien dokonywać ostrzeżenia o takim ryzyku. W dużej części nadzór makroostrożnościowy koncentruje się na nadzorze instytucji, które mogą mieć znacznie systemowe. Nadzór makroostrożnościowy ma również za zadanie stworzyć nowe i monitorować istniejące normy prawne

* Magister Monika Kępa jest doktorantką Doktorantka IX Edycji Studiów Doktoranckich Kolegium Ekonomiczno-Społecznego Szkoły Głównej Handlowej w Warszawie. E-mail: moniak77@poczta.fm.

1 Termin „makroostrożnościowy” został po raz pierwszy użyty w 1979 roku podczas spotkania Komitetu Cooke'a (poprzednika Bazylejskiego Komitetu ds. Nadzoru Bankowego). P. Clement, The Term Macroprudential: Origins and Evolution, „BIS Quarterly Review” 2010, March.

2 A. Hryckiewicz, M. Pawłowska, Czy nowy nadzór spetni swoje zadanie? Zmiany w nadzorze finansowym w Europie oraz ich konsekwencje dla Polski, ,Materiały i Studia NBP” 2013, nr 289, s. 7-8. 
i systemy zabezpieczeń, które mają ostrzegać i zapobiegać rozprzestrzenianiu się kryzysów finansowych. Celem nadzoru makroostrożnościowego jest również interweniowanie w przypadku pojawiających się problemów w sektorze finansowym.

Kryzys finansowy uwidocznił słabości regulacyjne, a także niekompletność sieci bezpieczeństwa finansowego. Prowadzenie nadzoru finansowego jedynie z perspektywy mikro okazało się jednak niewystarczające oraz nie było w stanie zapobiec akumulacji ryzyka systemowego. Przekonanie, iż rynek finansowy jest zdolny do działań korygujących (dyscyplina rynkowa okazała się być bardziej pojęciem tylko teoretycznym niż w rzeczywistości istniejącym mechanizmem wpływania na decyzje i działania podejmowane przez instytucję finansowe), było błędne. O ile przed kryzysem finansowym banki centralne publikowały ostrzeżenia i swoje analizy w Raportach o stabilności systemu finansowego ${ }^{3}$, to jednak postrzegano to bardziej jako element komunikacji z rynkiem niż działania w ramach polityki makroostrożnościowej. Główną przyczyną takiego stanu rzeczy był brak wyraźnego mandatu i odpowiednich instrumentów do działania w przypadku zidentyfikowania zagrożeń dla stabilności finansowej. W zasadzie dopiero w wyniku ostatniego kryzysu finansowego mandat banków centralnych został wzmocniony i uzupełniony o działania na rzecz stabilności systemu finansowego ${ }^{4}$.

\section{Polityka makroostrożnościowa nowy cel banku centralnego}

Doświadczenia ostatniego kryzysu prowadzą do wniosków, iż dotychczasowa budowa sieci bezpieczeństwa finansowego zawiera istotną lukę w postaci braku organu, który zajmowałby się monitorowaniem i identyfikacją zagrożeń dla stabilności systemu finansowego, jak również inicjowaniem działań mających na celu podejmowanie odpowiednich kroków zaradczych.

Istotny jest fakt, iż polityka makroostrożnościowa ma charakter prewencyjny, czyli zapobiega pojawianiu się zagrożeń, a nie zajmuje się zarządzaniem i rozwiązywaniem sytuacji kryzysowych. W tym celu działania podejmowane w ramach polityki makroostrożnościowej koncentrują się na identyfikowaniu, analizowaniu, monitorowaniu oraz przeciwdziałaniu ryzyku systemowemu. Przez pojęcie „ryzyko systemowe” rozumie się ryzyko wystąpienia zakłóceń w funkcjonowaniu systemu finansowego lub jego istotnej części, które może wywołać poważne negatywne skutki dla sfery realnej gospodarki. Analiza makroostrożnościowa powinna obejmować wszystkie potencjalne źródła ryzyka

\footnotetext{
3 Pierwszy taki raport opublikował Bank Anglii w 1996 roku. Narodowy Bank Polski publikuje Raport o stabilności systemu finansowego od 2001 roku.

4 O. Szczepańska, Stabilność finansowa jako cel banku centralnego. Studium teoretyczno-porównawcze, Scholar, Warszawa 2008, s. 67-72 oraz P. Smaga, Assessing Involvement of Central Banks in Financial Stability, Center For Financial Stability, Policy Paper, May 2013, s. 13.
} 
oraz cały system finansowy zarówno poprzez instytucje regulowane, jak i nieregulowane, a także relacje pomiędzy systemem finansowym i sferą realną gospodarki. Właśnie nieuwzględnienie powiązań i współzależności pomiędzy instytucjami finansowymi i rynkami okazało się słabością nadzoru mikroostrożnościowego ${ }^{5}$.

Najważniejszym celem polityki makroostrożnociowej jest dbałość o utrzymanie stabilności systemu finansowego jako całości z jednoczesnym zapobieganiem zjawiskom kryzysowym. Ze względu na fakt, iż stabilność finansowa nie jest pojęciem zdefiniowanym jednoznacznie ${ }^{6}$, a także jest trudna do skwantyfikowania, zidentyfikowanie celów pośrednich polityki makroostrożnościowej zwiększa zarówno możliwość jej operacjonalizacji, jak i przejrzystość. Niemniej jednak, uogólniając, można stwierdzić, że cele pośrednie dotyczą ograniczenia następujących niekorzystnych zjawisk, to jest:

1. Niedoboru płynności i problemów z finansowaniem się banków - problemy te wynikają z tego, że banki dokonują tak zwanej transformacji terminów, czyli finansują długoterminowe aktywa (kredyty) krótkoterminowymi pasywami (depozyty). Problem ten nasila przyjęcie przez banki nieodpowiednich modeli finansowania opartych w głównej mierze na niestabilnych źródłach, to jest rynek międzybankowy. Powoduje to, że w sytuacji napięć na rynkach dochodzi do gwałtownej wyprzedaży aktywów (tak zwana fire sale), efektów zarażania i zamrożenia płynności.

2. Nadmiernej akcji kredytowej i zbyt wysokiej dźwigni finansowej - nadmierna akcja kredytowa jest główną przyczyną boomów kredytowych i następujących po nich kryzysów finansowych. W latach 1970-2011 na 129 zidentyfikowanych kryzysów bankowych aż $45 \mathrm{z}$ nich poprzedził boom kredytowy?

Następnie wyszczególnionym celom pośrednim można przyporządkować konkretne instrumenty makroostrożnościowe. Instrumenty stosowane $\mathrm{w}$ ramach polityki makroostrożnościowej powinny być aktywowane, gdy zaobserwowano symptomy ryzyka systemowego, natomiast wycofywane w okresie dekoniunktury, aby nie stanowić dodatkowego obciążenia dla banków i zapewnić dopływ kredytu do gospodarki. Oznacza to, że polityka makroostrożnościowa powinna mieć charakter antycykliczny, uwzględniając fakt, iż ryzyko akumuluje się w fazie ekspansji kredytowej, a w okresie recesji dochodzi jedynie do materializacji nagromadzonego ryzyka ${ }^{8}$.

\footnotetext{
P. Szpunar, Rola polityki makroostrożnościowej w zapobieganiu kryzysom finansowym, „Materiały i Studia NBP" 2012, nr 278.

6 Należy wskazać, że w definiowaniu stabilności finansowej wyróżnia się dwa podejścia. Zgodnie z pierwszym, stabilność finansowa definiowana jest jako stan, w którym system finansowy prawidłowo wypełnia swoje funkcje nawet w sytuacji wystąpienia wstrząsów, natomiast według drugiego podejścia jako brak kryzysu finansowego.

7 Laeven, F. Valencia, Systemic Banking Crises Database: An Update, „IMF Working Paper” 2012, no. WP/12/163, s. 10.

A. Dobrzańska, Polityka makroostrożnościowa - zagadnienia instytucjonalne. Teoria i dotychczasowe doświadczenia w Unii Europejskiej, „Materiały i Studia NBP” 2014, nr 307.
} 


\section{Organ polityki makroostrożnościowej}

Nadzór makroostrożnościowy stanowi nowy element sieci bezpieczeństwa finansowego. Warunkiem skuteczności i jednocześnie pierwszym krokiem stworzenia ram polityki makroostrożnościowej jest zaprojektowanie i wdrożenie odpowiednich rozwiązań instytucjonalnych. Z dotychczasowej dyskusji wynika, że trudno wskazać jeden optymalny model instytucjonalnej organizacji nadzoru makroostrożnościowego. Wybór konkretnego rozwiązania instytucjonalnego jest uzależniony głównie od dotychczasowej organizacji sieci bezpieczeństwa finansowego i współpracy pomiędzy instytucjami w zakresie stabilności finansowej w danym kraju. Niemniej jednak można wskazać na pewne pożądane elementy, które powinien uwzględniać mandat makroostrożnościowy.

Podstawową kwestią jest wyraźne wskazanie instytucji odpowiedzialnej za nadzór makroostrożnościowy, czyli przyznanie mandatu makroostrożnościowego konkretnemu organowi. Mandat ten może posiadać pojedyncza instytucja lub ciało kolegialne w postaci odrębnego komitetu, w skład którego wchodzą instytucje krajowej sieci bezpieczeństwa finansowego. W przypadku umiejscowienia odpowiedzialności za nadzór makroostrożnościowy w jednej instytucji, na przykład banku centralnym, konieczne jest zapewnienie odpowiednich mechanizmów współpracy pomiędzy organem makroostrożnościowym a innymi instytucjami, których działania mają wpływ na stabilność finansową. Powierzenie mandatu jednej instytucji najczęściej wynika $z$ dotychczasowej konstrukcji sieci bezpieczeństwa finansowego. Przykładowo, gdy mikroostrożnościowy nadzór finansowy jest zintegrowany i ulokowany w banku centralnym, optymalnym rozwiązaniem jest również powierzenie funkcji makroostrożnościowej tej instytucji. Niemniej jednak nawet w takim przypadku konieczne jest zapewnienie odpowiedniej współpracy pomiędzy organem makroostrożnościowym a ministerstwem finansów ${ }^{9}$.

Interwencja i zaangażowanie banków centralnych oraz organów nadzoru finansowego w politykę makroostrożnościową wynikają z funkcji, jakie pełnią te instytucje. Banki centralne są zainteresowane utrzymaniem stabilności finansowej z dwóch głównych powodów. Po pierwsze, jako instytucje odpowiedzialne za politykę monetarną dbają o stabilność cen, która jest ściśle powiązana ze stabilnością finansową. W warunkach stabilnego systemu finansowego kanały transmisji polityki pieniężnej działają poprawnie, co ułatwia prowadzenie wiarygodnej polityki monetarnej. Po drugie, banki centralne pełnią tradycyjnie funkcję pożyczkodawcy ostatniej instancji i w sytuacji kryzysowej mogą sięgnąć po niestandardowe instrumenty polityki pieniężnej. Skuteczna polityka makroostrożnościowa i stabilny system finansowy zmniejszają prawdopodobieństwo

9 C. Borio, Towards a Macroprudential Framework for Financial Supervision and Regulation?, BIS Working Paper no. 128, Bank for International Settlements 2003 oraz A. Crockett, Marrying the Microand Macro-prudential Dimensions of Financial Stability, Bank for International Settlements 2000. 
stosowania takich niekonwencjonalnych działań. Stąd też już obecnie w wielu krajach banki centralne angażują się w działania na rzecz stabilności systemu finansowego. Za ich kluczową rolą w polityce makroostrożnościowej przemawia wiele argumentów, przede wszystkim ich ugruntowana prawnie niezależność, reputacja i autorytet, a także wiedza ekspercka i doświadczenie w zakresie przeprowadzania analiz makroekonomicznych i ryzyka systemowego oraz umiejętność komunikacji z rynkiem. Ponadto, niektóre banki centralne są także zaangażowane w nadzór mikroostrożnościowy ${ }^{10}$, przez co dysponują danymi na temat nadzorowanych podmiotów.

Z kolei zaangażowanie organu (organów) nadzoru mikroostrożnościowego wynika z interakcji, które zachodzą pomiędzy polityką mikro- i makroostrożnościową, a także z faktu, że instrumenty polityki makroostrożnościowej to głównie dotychczasowe narzędzia nadzoru mikroostrożnościowego odpowiednio skalibrowane i zastosowane z perspektywy systemowej. Istotną kwestią są również dane i informacje o podmiotach nadzorowanych, znajdujące się w posiadaniu nadzorcy, które są niezbędne do realizacji zadań organu makroostrożnościowego.

Należy podkreślić, że organy o podobnym składzie istniejąjuż w wielu krajach Unii Europejskiej, są to jednak struktury, które powstały na podstawi Memorandum of Understanding 200830 i są one przeznaczone do zarządzania sytuacją kryzysową. Ze względu na prewencyjny charakter polityki makroostrożnościowej, a także z uwagi na dominującą rolę ministerstwa finansów w komitetach kryzysowych wskazane jest utworzenie odrębnego komitetu dedykowanego tylko kwestiom makroostrożnościowym ${ }^{11}$.

Nadzór makroostrożnościowy do tej pory został umiejscowiony w banku centralnym w ośmiu krajach Unii. Są to: Czechy, Grecja, Irlandia, Łotwa, Malta, Portugalia, Słowacja i Węgry. W kolejnych czterech krajach (Belgia, Cypr, Estonia, Litwa) planuje się także powierzyć zadania z zakresu polityki makroostrożnościowej tej właśnie instytucji.

Nadzór makroostrożnościowy może też być ulokowany w organie nadzoru mikroostrożnościowego, jak to uczyniono w Szwecji i jak planuje się w Finlandii ${ }^{12}$.

Analizując powyższe przypadki, widać, że w czterech krajach (Czechy, Irlandia, Słowacja i Węgry) bank centralny jest również odpowiedzialny za mikroostrożnościowy nadzór nad całym sektorem finansowym. Powierzenie dodatkowych zadań w zakresie polityki makroostrożnościowej tej instytucji było rozwiązaniem optymalnym. W przypadku Portugalii bank centralny jest odpowiedzialny jedynie za nadzór nad sektorem

10 Obecnie banki centralne w 18 krajach UE są zaangażowane w nadzór nad sektorem bankowym, a w $5 \mathrm{z}$ nich pełnią nadzór nad całym systemem finansowym.

11 International Monetary Fund, Key Aspects of Macroprudential Policy, June 2013 oraz E. Nier, J. Osiński, L. Jacome, P. Madrid, Towards Effective Macroprudential Policy Frameworks: An Assess Ment of Stylized Institutional Models, „IMF Working Paper” 2011, no. WP/11/250.

12 Opinion of the European Central Bank of 2 December 2013 on the prudential supervision of credit institutions and on macroprudential oversight (CON/2013/82). 
bankowym, a w Grecji - za nadzór nad sektorem bankowym i ubezpieczeniowym. Natomiast banki centralne Malty i Łotwy nie posiadają żadnych kompetencji nadzorczych, a nadzór nad całym rynkiem finansowym jest sprawowany przez odrębne instytucje nadzorcze. W takim przypadku konieczne jest zapewnienie odpowiednich mechanizmów kooperacji. Przykładowo, na Malcie powołano w tym celu Wspólną Radę Stabilności Finansowej ( Joint Financial Stability Board) ${ }^{13}$, która jest platformą współpracy pomiędzy bankiem centralnym i organem nadzorczym w sprawach związanych z prowadzeniem polityki makroostrożnościowej.

\section{Podsumowanie}

Wnioski z ostatniego kryzysu finansowego ukazały, iż dotychczasowa konstrukcja sieci bezpieczeństwa finansowego zawierała istotną lukę w postaci braku organu, który zajmowałby się monitorowaniem i identyfikacją zagrożeń dla stabilności finansowej, jak również podejmowaniem odpowiednich działań zaradczych. Brakowało instytucji, która nie tylko identyfikowałaby ryzyko systemowe, ale także miała odpowiednie uprawnienia i instrumenty do przeciwdziałania zidentyfikowanym zagrożeniom dla stabilności finansowej.

W odpowiedzi na wyżej przedstawione słabości dotychczasowego systemu reforma regulacyjna obejmuje ustanowienie formalnoprawnych ram polityki makroostrożnościowej. Dlatego też konieczne jest wyraźne wskazanie instytucji odpowiedzialnej za politykę makroostrożnościową. Jej mandat powinien zawierać cel działalności oraz wyszczególnione zadania, jak również określone uprawnienia i instrumenty, które pozwolą na realizację stawianych przed nią wyzwań. Ważną kwestią jest także zapewnienie odpowiednich mechanizmów współpracy zarówno na szczeblu krajowym, jak i w wymiarze międzynarodowym. Istotnymi aspektami takiego mandatu są też niezależność, transparentność i demokratyczna odpowiedzialność organu makroostrożnościowego.

W Unii Europejskiej katalizatorem zmian instytucjonalnych w zakresie polityki makroostrożnościowej było utworzenie Europejskiej Rady ds. Ryzyka Systemowego, a następnie wydanie przez nią Zalecenia w sprawie mandatu makroostrożnościowego organów krajowych. W efekcie w momencie ukończenia pracy nad niniejszym artykułem w 18 państwach członkowskich istnieją już organy makroostrożnościowe, w kolejnych 8 prowadzone są prace zmierzające do ich ustanowienia. Dotychczasowe doświadczenia europejskie w zakresie rozwiązań instytucjonalnych nie pozwalają na wskazanie jednego dominującego modelu. Dziewięć krajów Unii powierzyło mandat makroostroż-

13 Memorandum of Understanding between the Central Bank of Malta and the Malta Financial Services Authority, January 2013, www.centralbankmalta.org/updates/Downloads/pdfs/mou_JFSB.pdf(25.01.2013). 
nościowy pojedynczej instytucji i tyle samo krajów utworzyło odrębny międzyinstytucjonalny organ makroostrożnosciowy, w skład którego wchodzą przede wszystkim trzy główne instytucje sieci bezpieczeństwa finansowego: bank centralny, organ nadzorczy i ministerstwo finansów. W przypadku krajów, które zdecydowały się ulokować kompetencje makroostrożnościowe w jednej instytucji, najczęściej tą instytucją jest bank centralny. W drugiej kolejności uprawnienia takie są też przyznawane organom nadzoru mikroostrożnościowego. Należy zatem zwrócić uwagę na to, że zupełnie nieobecne jest rozwiązanie polegające na przyznaniu mandatu makroostrożnościowego wyłącznie ministerstwu finansów czy innej instytucji sieci bezpieczeństwa finansowego.

\section{Literatura}

Borio C., Towards a Macroprudential Framework for Financial Supervision and Regulation?, BIS Working Paper no. 128, Bank for International Settlements 2003.

Clement P., The Term Macroprudential: Origins and Evolution, „BIS Quarterly Review” 2010, March.

Crockett A., Marrying the Micro- and Macro-prudential Dimensions of Financial Stability, Bank for International Settlements 2000.

Dobrzańska A., Polityka makroostrożnościowa - zagadnienia instytucjonalne. Teoria i dotychczasowe doświadczenia w Unii Europejskiej, „Materiały i Studia NBP” 2014, nr 307.

Hryckiewicz A., Pawłowska M., Czy nowy nadzór spetni swoje zadanie? Zmiany w nadzorze finansowym w Europie oraz ich konsekwencje dla Polski, „Materiały i Studia NBP” 2013, nr 289.

Laeven L., Valencia F., Systemic Banking Crises Database: An Update, „IMF Working Paper” 2012, no. WP/12/163.

Memorandum of Understanding between the Central Bank of Malta and the Malta Financial Services Authority, January 2013.

Nier E., Osiński J., Jacome L., Madrid P., Towards Effective Macroprudential Policy Frameworks: An Assess Ment of Stylized Institutional Models, „IMF Working Paper” 2011, no. WP/11/250.

Opinion of the European Central Bank of 2 December 2013 on the prudential supervision of credit institutions and on macroprudential oversight (CON/2013/82).

Smaga P., Assessing Involvement of Central Banks in Financial Stability, Center For Financial Stability, Policy Paper, May 2013.

Szczepańska O., Stabilność finansowa jako cel banku centralnego. Studium teoretyczno-porównawcze, Scholar, Warszawa 2008;

Szpunar P., Rola polityki makroostrożnościowej w zapobieganiu kryzysom finansowym, „Materiały i Studia NBP” 2012, nr 278. 


\section{Streszczenie}

W niniejszym opracowaniu przedstawiona została rola oraz narzędzia polityki makroostrożnościowej, która stanowi nowe wyzwanie dla banku centralnego z powodu niedoskonałości dotychczasowych sposobów zapobiegania niestabilności finansowej, a także spełnia istotną rolę w oddziaływaniu na stabilność sektora bankowego.

Doświadczenia ostatniego kryzysu finansowego prowadzą do wniosku, iż dotychczasowa konstrukcja sieci bezpieczeństwa finansowego zawierała istotną lukę w postaci braku organu, który zajmowałby się nie tylko monitorowaniem i identyfikacją zagrożeń dla stabilności finansowej, ale również podejmowaniem działań w celu ich złagodzenia i ograniczenia. W odpowiedzi na tę słabość dotychczasowego systemu reforma regulacyjna obejmuje ustanowienie formalno prawnych ram polityki makroostrożnościowej. Artykuł ma na celu przedstawienie kwestii związanych z organizacją polityki makroostrożnościowej. Zawiera on zarówno omówienie zagadnień teoretycznych, jak i analizę dotychczasowych doświadczeń.

\section{Macro-prudential policy as a new challenge for the central bank}

In the herein publication I will discuss the role of and vehicles for macro-prudential policy in affecting stability of banking sector. The experience of the latest financial crisis leads to the conclusion that the past structure of financial security system lacked an organ monitoring and identifying threats to financial stability, but also taking measures to reduce and constrain them. In response to this weakness of the system a regulatory reform that encompasses laying down formal and legal frameworks of macro-prudential policy has emerged. Therefore, this publication aims to present issues connected with organization of macro-prudential policy. The release includes theoretical issues as well as an analysis of the financial crisis standpoint. 